\title{
Temperature and Alternative Hosts Influence Aceria tosichella Infestation and Wheat Streak Mosaic Virus Infection
}

Nar B. Ranabhat and Tim Seipel, Department of Land Resources and Environmental Sciences, Montana State University, Bozeman 59717; Erik A. Lehnhoff, Department of Entomology, Plant Pathology and Weed Science, New Mexico State University, Las Cruces 88003; Zach J. Miller, Department of Research Centers, Western Agricultural Research Center, Montana State University, Corvallis 59828; and Karl E. Owen, Department of Plant Sciences and Plant Pathology, Fabian D. Menalled, Department of Land Resources and Environmental Sciences, and Mary E. Burrows, ${ }^{\dagger}$ Department of Plant Sciences and Plant Pathology, Montana State University, Bozeman

\begin{abstract}
Wheat streak mosaic, caused by Wheat streak mosaic virus (WSMV; family Potyviridae), is the most important and common viral disease of wheat (Triticum aestivum L.) in the Great Plains of North America. WSMV is transmitted by the wheat curl mite (WCM; Aceria tosichella). We evaluated how mean daily temperatures, cumulative growing degree-days, day of the year, and surrounding alternative host identity affected WCM infestation and WSMV infection of wheat from late summer through early autumn in Montana, United States. Cumulative growing degree-days, warm mean daily temperatures (i.e., $>10^{\circ} \mathrm{C}$ ), and surrounding alternative hosts interacted

to alter risk of WCM infestation and WSMV infection. Wheat surrounded by Bromus tectorum L. and preharvest volunteer wheat had WCM infestation and WSMV infection rates of $88 \%$ in years when the mean daily temperature was $15^{\circ} \mathrm{C}$ in October, compared with $23 \%$ when surrounded by bare ground, and $<1 \%$ when the temperature was $0^{\circ} \mathrm{C}$ regardless of surrounding alternative host. Mean daily temperatures in the cereal-growing regions of Montana during autumn are marginally conducive to WCM population growth and movement. As the region continues to warm, the period of WCM movement will become longer, potentially increasing the frequency of WSMV outbreaks.
\end{abstract}

Effective and sustainable management of plant viral diseases must be based on ecologically and epidemiologically sound strategies that minimize the risk of epidemics and associated crop losses (Jeger et al. 2004; Jones 2014; Juroszek and von Tiedemann 2011; Madden et al. 2007; Scholthof 2007). In this context, strategies must be developed that account for the interactive effects among the environment, host, and vector of the pathogen (Scholthof 2007). When successfully implemented, these strategies can limit vector abundance, seasonal movement, and the potential of alternative or reservoir hosts to harbor the pathogen. Thereby, the risk of disease outbreaks is reduced and the economic effects of plant viral diseases limited (Cunniffe et al. 2015; Jeger et al. 2004).

Wheat streak mosaic, a plant viral disease caused by Wheat streak mosaic virus (WSMV; family Potyviridae, genus Tritimovirus), is the most important and common plant viral disease of wheat (Triticum aestivum L.) in the Great Plains of North America (Burrows et al. 2016). WSMV occurs around the globe, including in Eurasia, Australia, and both North and South America (French and Stenger 2003; Navia et al. 2013). In the Great Plains, yield losses due to WSMV reportedly range from 13 to $70 \%$ in the field and up to $100 \%$ yield loss in experimental trials (Bockus et al. 2001; Lehnhoff et al. 2015; Rahman et al. 1974; Sharp et al. 2002). Factors affecting severity of WSMV symptoms and yield reductions include crop stage at infection (Hunger et al. 1992), cultivar susceptibility, water availability, amount and types of fertilizers applied, and weatherconditions (Dordas 2008; Lehnhoff et al. 2015; Miller et al. 2015; Velandia et al. 2010).

WSMV requires the wheat curl mite (WCM; Aceria tosichella) as a vector (Slykhuis 1955). For WSMV to infect the next year's cereal

${ }^{\dagger}$ Corresponding author: M. E. Burrows; E-mail: mburrows@montana.edu

N. R. Ranabhat and T. Seipel share first authorship.

This project was supported with funding from United States Department of Agriculture-National Institute for Food and Agriculture (USDA-NIFA) grant number 2013-68004-20358.

*The $\boldsymbol{e}$-Xtra logo stands for "electronic extra" and indicates that one supplementary file is published online.

Accepted for publication 4 October 2017.

() 2018 The American Phytopathological Society crop, virus-infected WCM move to and survive or reproduce on alternative grassy hosts. The WCM is a species complex comprising many biotypes and putative species that can survive on more than 80 grass species, including grassy weeds and cereal crops. Lineages differ in host specificity and affinity (Navia et al. 2013; Skoracka et al. 2017; Somsen and Sill 1970; Thomas and Hein 2003). Alternative hosts serve as a "green bridge" of live plant material that is present between harvesting of one crop and planting of the next (Slykhuis 1955). Common alternative hosts in the Northern Great Plains include downy brome or cheatgrass (Bromus tectorum L.), green foxtail (Setaria viridis (L.) P. Beauv.), and volunteer wheat (T. aestivum) that germinates just before, during, or immediately after wheat harvest (Connin 1956; Ito et al. 2012; Somsen and Sill 1970).

Previous greenhouse and field studies indicate that green bridge grasses vary in their ability to serve as a host for the WCM and WSMV (Ito et al. 2012). This variation is partially related to diversity within the WCM species complex (Skoracka et al. 2017). In general, grass host quality and abundance affect seasonal rates of plant virus transmission (Jeger et al. 2004; Watson et al. 1975). In addition, weather conditions influence WCM movement from alternative hosts to next year's winter wheat. For example, cold temperatures (i.e., temperatures near $0^{\circ} \mathrm{C}$ ) limit WCM movement but temperatures near $10^{\circ} \mathrm{C}$ and high humidity allow the WCM to survive off-host for the longest period (up to $200 \mathrm{~h}$ ) and, when on a living host, lead to an intrinsic population growth rate greater than one, resulting in increased vector numbers (Kuczyński et al. 2016; Wosula et al. 2015). It was hypothesized that, when mean temperatures are warm in the autumn (i.e., mean daily temperature is $>10^{\circ} \mathrm{C}$ ), both the WCM infestation and incidence of WSMV on crops will be greater. Also, due to the differential impact of hosts species on WCM population growth, occurrence of WCM and WSMV infection on wheat plants is hypothesized to be influenced by surrounding alternative host species. To test these hypotheses, the role of temperature and surrounding alternative host species on prevalence of WCM infestation and WSMV infection of wheat was assessed. Two questions were posed: (i) Do temperature conditions in autumn affect WCM incidence and WSMV infection in wheat? and (ii) Do surrounding alternative hosts affect the WCM incidence and WSMV infection in wheat?

\section{Materials and Methods}

Site description. The questions were addressed in a field experiment conducted during late summer and early autumn in 2013, 
2014, and 2015 at the Arthur H. Post Agronomy Research Farm, Bozeman, MT $\left(45^{\circ} 40^{\prime} 29^{\prime \prime} \mathrm{N}, 111^{\circ} 09^{\prime} 14^{\prime \prime} \mathrm{W}, 1,423 \mathrm{~m}\right.$ in elevation). The soil type at the farm is Amsterdam-quagle silt loam (USDANRCS 2015). WCM infestation and WSMV infection of plots relied on natural inocula from the surrounding area. The WCM were collected, mounted, and positively identified using morphological characteristics (Skoracka 2004).

Temperature and cumulative growing degree-days data. To predict variation in WCM incidence and WSMV infection through autumn in response to temperatures and cumulative growing degreedays (GDD), meteorological data obtained from the United States Bureau of Reclamation Great Plains AgriMet station (Arthur H. Post Research Farm BOZM; https://www.usbr.gov/gp/agrimet/) (USBR 2015) were compiled. The daily mean, minimum, and maximum temperature during the length of this study (2013 to 2015) were used to calculate cumulative GDD of spring wheat. GDD was calculated as the sum per day of the midpoint between daily maximum and minimum temperature minus the base temperature. The base temperature used for wheat was $0^{\circ} \mathrm{C}$ (McMaster and Wilhelm 1997). If the daily midpoint temperature was less than the base, no GDD were accumulated for the given day. The planting date of spring wheat at the study site was used to set the starting point for GDD calculation. GDD was subsequently used to predict WCM infestation and WSMV infection because, as wheat reaches maturity and senesces at 1,500 to 1,600 GDD (Miller et al. 2001), WCM migrate off wheat plants to alternative hosts before infesting next year's crop. The mean daily temperature 7 and 3 days before the weekly sampling date, defined as the day on which trap plants were exchanged (see below) was calculated, and the mean daily temperature on the day of sampling also was calculated (i.e., the midpoint between minimum and maximum temperatures).

Field experiment design. Each year, alternative host treatments were arranged in a randomized complete block design with six blocks. Plots were 2 by $2 \mathrm{~m}$ and alleys between plots were approximately $2.5 \mathrm{~m}$ wide and maintained weed free using the herbicide glyphosate and tillage. Alternative hosts included (i) spring-emerged B. tectorum (spring downy brome) (ii) B. tectorum that emerged in the previous autumn (fall downy brome), (iii) preharvest volunteer wheat, (iv) postharvest volunteer wheat, (v) maize (Zea mays L), and (vi) green foxtail (S. virdis). The placement of control plots varied between the 3 years in which the study was conducted. In 2013, bare-ground control plots were placed around the perimeter of the experimental blocks at each of the four cardinal directions. In 2014 and 2015, the bare-ground control treatment was assigned randomly within each block. In 2015, the experiment had only three treatment levels: bare ground, preharvest volunteer wheat, and spring-emerged downy brome to concentrate on the most common green bridge species at the experimental farm, based on the 2013 and 2014 results.

Alternative hosts were seeded by hand. Spring downy brome was seeded early in June 2013, 2014, and 2015 at a rate of 1,600 seeds $/ \mathrm{m}^{2}$. Fall downy brome plots were established from naturally emerging downy brome in the autumn and plant density was approximately 1,000 plants $/ \mathrm{m}^{2}$. Preharvest volunteer wheat (cultivar Neeley) plots were planted by scattering and lightly incorporating seed on plots at a rate of 100 seeds $/ \mathrm{m}^{2}$ during early July 2013, 2014, and 2015. Postharvest volunteer wheat plots were hand planted around 1 August 2013 and 2014. Maize (var. Rugose, Early Sunglow hybrid 4.50) was planted in early June 2013 and 2014 with 10-cm seed spacing, resulting in 80 seeds $\mathrm{m}^{-2}$. Due to low emergence and difficulty of growing maize in semiarid dryland conditions, in 2014, a maize variety better adapted for semiarid dryland conditions was used (variety P8107HR; Pioneer). Green foxtail was seeded in first week of June 2013 and 2014 at a rate of 9,400 seeds $/ \mathrm{m}^{2}$.

WCM and WSMV sampling on trap plants. To monitor WCM infestation and WSMV infection, winter wheat trap plants (cultivar Neeley) were placed weekly in the center of each 2-by-2-m plot and monitored for number of WCM and incidence of WSMV. Prior to deploying trap plants, they were grown in cones $(3.8 \mathrm{~cm}$ in diameter and $21 \mathrm{~cm}$ in depth; Ray Leach, model SC10; Stuewe \& Sons) for approximately two and a half weeks to $\mathrm{BBCH}$ scale 13 (three leaves unfolded) in greenhouse conditions. Four cones, each containing one trap plant, were inserted into four holes drilled in a $15-\mathrm{cm}^{2}$ piece of rigid plastic placed in a piece of plywood $\left(30 \mathrm{~cm}^{2}\right.$ by $\left.0.63 \mathrm{~cm}\right)$. This structure was then placed onto a plastic bucket $(17.8 \mathrm{~cm}$ in diameter by $18 \mathrm{~cm}$ deep) filled with water. The bucket was inserted into a hole excavated in the soil. such that the top of the bucket was flush with the soil surface. Trap plants were covered with a screen made with 1.3-by-1.3-cm openings to protect them from grazing animals and hail.

In Montana, typical winter and spring wheat harvest dates range from early August to mid-September, and typical winter wheat planting is from September to mid-October (USDA-NASS 2015). Trap plants were placed in plots weekly from 2 August to 25 October 2013, 5 August to 28 October 2014, and 1 August to 31 October 2015. This period was selected because it spans the time range when WCM move from wheat to the next year's winter wheat crop and alternative hosts. Trap plants were placed in a plot for 1 week, then removed and placed in the greenhouse under the growing conditions described above. In the greenhouse, WCM movement among wheat plants was prevented by covering them with plastic cages (Visipak; clear plastic tubes $3.8 \mathrm{~cm}$ in diameter by $61 \mathrm{~cm}$ in height) with three vent holes $(2.5$ by $5 \mathrm{~cm})$ cut in each tube and covered with a $25-\mu \mathrm{m}$ nylon mesh (Sefar AG). All trap plants were kept for 2 weeks in the greenhouse. At the end of the 2-week period, the presence or absence of WCM was recorded on each wheat trap plant after visually searching each plant using a $\times 30$ to $\times 50$ stereomicroscope. In addition, one young fully expanded leaf from each plant was used for WSMV detection by enzyme-linked immunosorbent assay (ELISA), as described below.

Detection of WSMV. Infection of WSMV in trap plants was evaluated by using an indirect ELISA, with each individual leaf segment processed separately (Ito et al. 2012). Within a plate, every 10th well had a negative control (i.e., sample from healthy wheat plant) to reduce potential bias in values of optical density caused by position of samples. The mean and standard deviation of the negative control on each plate were calculated. Samples above three standard deviations were considered infected with WSMV (Miller et al. 2014).

Analysis of WCM infestation and WSMV infection. To assess variation in WCM infestation and WSMV infection on wheat trap plants in response to temperature and alternative host identity, generalized linear mixed-effect models were fit with binomial distribution and logit link for each response variable of proportional successes. All statistical analyses were conducted in R; linear mixed-effects models were fit using the R package lme4 (Bates et al. 2015; R Development Core Team 2014). The response variables were the proportion out of the total number of wheat trap plants with WCM present and the proportion of trap plants that tested positive for WSMV in each plot.

Covariation of bioclimatic variables and model building. Temperature and GDD variables were expected to be the most limiting factors to WCM infestation and WSMV infection because of temperature constraints on WCM population growth and movement (Kuczyński et al. 2016) and maturity and senescence of wheat predicted by GDD. To begin, an iterative model-fitting process using different temperature variables, including GDD, mean temperature on the day of sampling, and mean daily temperature 3 and 7 days before sampling was conducted. Akaike's Information Criterion (AIC) (Burnham and Anderson 2002) was used to compare models. The model with the lowest AIC was considered to best describe the data relative to the other models. To determine which temperature variable best accounted for variation in WCM infestation and WSMV incidence, first, the correlation among variables was compared. If correlation among variables was greater than $70 \%$, we did not include them in the same model to reduce the impact of autocorrelation (Graham 2003). Because some variables were greater than $70 \%$ correlated, first univariate models were compared to determine which variable best described the data. A new set of models was then fitted with the remaining climate variables that also included the interaction of temperature variables. From the new set of models, the model that had the lowest AIC was selected. Alternative host was then added to the model, the interaction of bioclimatic variables and alternative host species was assessed, and the model with the lowest AIC was 
selected. In the mixed-effects models, experimental block was fit as a random effect to account for grouping. The coefficient of determination $\left(R^{2}\right)$ was calculated using the method of Nakagawa and Schielzeth (2013).

Finally, it was recognized that there were two approaches possible to understand the variation in WCM infestation and WSMV infection. The first was a bioclimatic approach (i.e., using GDD, temperature variables, and alternative hosts) and the second was variation in day of the year across years (i.e., a second order polynomial form of day of the year, year, alternative host, and their interactions). To compare the two approaches and validate bioclimatic models, models of WCM infestation and WSMV infection were compared based on bioclimatic variables to the models that contained just variation in time. Alternative host and interactions were included in the bioclimatic models and the models using only time variables if they had the lowest AIC relative to the other bioclimatic or models using day and year.

\section{Results}

Covariation of bioclimatic variables. As expected, mean daily temperatures declined as day of the year increased in late summer and early autumn but this relationship varied among years (Fig. $1 \mathrm{~A}$; day of the year $\mathrm{F}_{1,1216}=1929, P<0.001$; year $\mathrm{F}_{2,1216}=$ 221.6, $P<0.001$; day of the year-year $\mathrm{F}_{2,1216}=920.3, P<0.001$ ). Temperature variables during the period when WCM infestation and WSMV infection were sampled were highly correlated but temperature variables were, on average, only $52 \%$ correlated with GDD (Table 1). Mean daily temperature during late summer and early autumn was lowest in $2013\left(13.7^{\circ} \mathrm{C}\right)$, warmer in $2014\left(14.4^{\circ} \mathrm{C}\right)$, and highest in $2015\left(18.9^{\circ} \mathrm{C}\right)$. The years 2013 and 2015 contrasted markedly, with mean daily temperatures well below $10^{\circ} \mathrm{C}$ during autumn 2013 and temperatures near $20^{\circ} \mathrm{C}$ in late autumn 2015 (Fig. 1A). GDD at the start of the field experiment in late summer differed among years $(1,566,1,399$, and 1,426 in 2013,2014 , and 2015 , respectively; Fig. 1B) and the average increase of GDD differed during late summer and early autumn period among years (13.7 in 2013, 11.5 in 2014, and 15.3 in 2015; Fig. 1B).

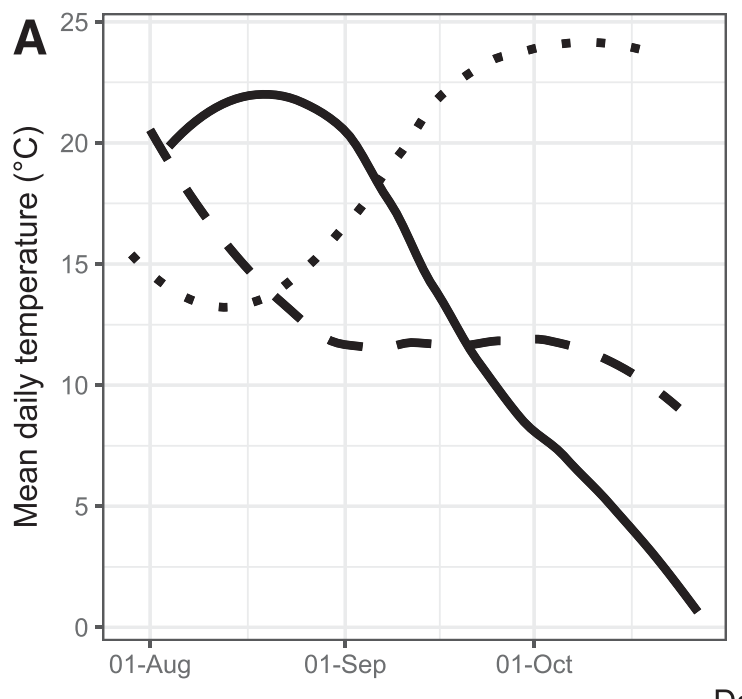

Date
WCM infestation and WSMV infection in response to bioclimatic variables and alternative host. Both WCM infestation and WSMV infection varied in response to bioclimatic variables, identity of alternative host surrounding trap plants, and interaction between bioclimatic variables and alternative host identity. The models for both WCM infestation and WSMV infection with the lowest AIC contained mean temperature on the day of sampling and alternative host identity. Their interaction explained 35 and $36 \%$ of the variation of the models of WCM infestation and WSMV infection, respectively (Tables 2 and 3 ).

Across years, proportion of wheat trap plants infested with WCM was positively correlated with mean temperature on the day of sampling $(r=0.42, t=15.8, \mathrm{df}=1,192, P<0.001)$ and GDD $(r=0.14, t=-4.8, \mathrm{df}=1,192, P<0.001)$. Incidence of WSMV on trap plants was positively correlated with mean temperature on the day of sampling $(r=0.18, t=6.10, \mathrm{df}=1,186$, $P<0.001)$ but, overall, there was a negative correlation between GDD and proportion of trap plants infected with WSMV $(r=-0.26$ $t=-9.4$, df $=1,186, P<0.001)$. Both the GDD and mean temperature on the day of sampling interacted to describe the proportion of WCM infested trap plants and the proportion of trap plants infected with WSMV (Tables 2 and 3). To chart variation and display both WCM infestation and WSMV infection without three-dimensional graphics, day of the year on the $\mathrm{x}$-axis, which was highly correlated with the interaction of mean daily temperature and GDD across all years, was used (day of the year $=4.72(\mathrm{GDD})-2.47$ (mean daily temperature $)+0.0007(\mathrm{GDD} \times$ mean daily temperature $) ; \mathrm{F}_{(3,1280)}=$ 3030, $P<0.001, R^{2}=0.89$; Fig. 2).

Maximum incidence of WCM on trap plants (between 75 and $100 \%$ of plants) was similar in all years yet timing of maximum occurrence differed across years (Fig. 2). In 2013, incidence of WCM on trap plants declined rapidly as mean daily temperatures decreased below $10^{\circ} \mathrm{C}$ near 1 September (Figs. 1 and 2). In 2014 and 2015, a high incidence of WCM was recorded throughout late summer and early autumn as temperatures remained above $10^{\circ} \mathrm{C}$ in 2014 and well above $15^{\circ} \mathrm{C}$ in 2015 .

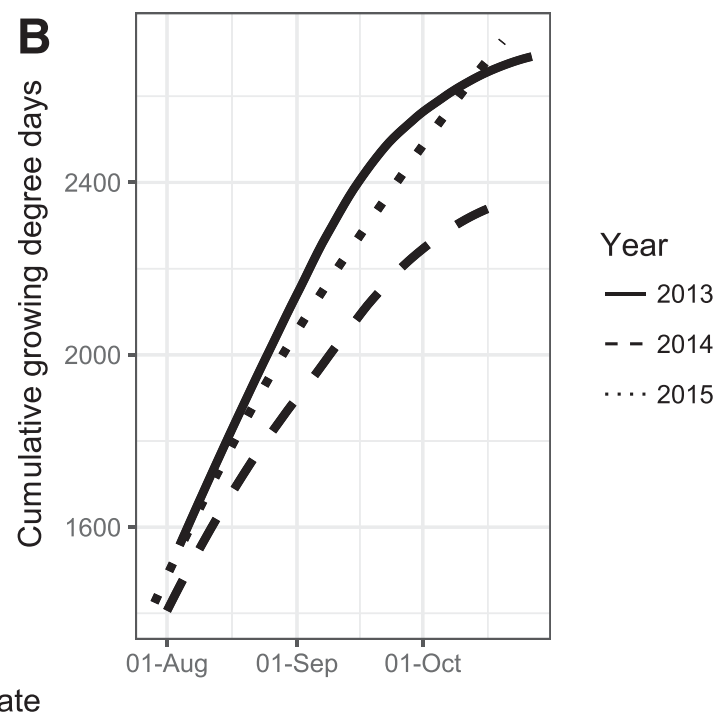

Fig. 1. A, Mean average daily temperature from late summer and through early autumn. Line types represent the different years $(2013=$ solid, $2014=$ dashed, and $2015=$ dotted). B, Accumulation of the cumulative number of growing degree-days as a function of day of the year in Bozeman, MT.

Table 1. Correlation among day of the year, temperature variables, and cumulative growing degree-days (GDD) through autumn 2013, 2014, and 2015 at the Arthur H. Post farm in Bozeman MT

\begin{tabular}{lcccc}
\hline Variables & Day of the year & Mean daily temperature & Mean temperature prior 3 days & Mean temperature prior 7 days \\
\hline Day of the year & 1 & $\ldots$ & $\ldots$ & $\ldots$ \\
Mean temperature on day of sampling & -0.60 & 1 & $\ldots$ & $\ldots$ \\
Mean temperature 3 days prior & -0.62 & 0.92 & 1 & $\ldots$ \\
Mean temperature 7 days prior & -0.64 & 0.88 & -0.96 & 1 \\
Cumulative GDD & 0.92 & -0.50 & -0.52 & -0.56 \\
\hline
\end{tabular}


In 2013, the peak period of WSMV infection of trap plants occurred in late August through early September, between 1,700 and 1,900 GDD, but overall maximum infection rate was less than in 2014 and 2015 (Fig. 2B). In 2014 and 2015, WSMV infection rates were highest later in the season, when more GDD had accumulated, but only when daily temperature remained above $10^{\circ} \mathrm{C}$ (Fig. 2). For both models of WCM infestation and WSMV infection, the interaction of mean daily temperature and GDD explained the most variation (Table 3).

In 2013, when mean temperature declined, beginning in early September and dropped to near $0^{\circ} \mathrm{C}$ by 1 October (Fig. 1), there were few differences in incidence of WCM infestation and WSMV infection among alternative host treatments (Fig. 2). Proportion of WCMinfested trap plants surrounded by corn and postharvest volunteer wheat plots were similar to proportion of trap plants infested in the control plots (Fig. 2). In 2014 and 2015, when mean daily temperatures were higher, trap plants surrounded by spring downy brome and preharvest volunteer winter wheat had the highest rates of WCM and WSMV in late autumn (Fig. 2).

In 2013, the proportion of trap plants infected with WSMV was highest when plants were surrounded by preharvest volunteer wheat in mid-August $(1,700 \mathrm{GDD} ; P=0.01)$ and maize and postharvest volunteer wheat in the last 2 weeks of August (1,850 to 2,280 GDD; $P<0.001)$. In 2013, lowest rates of infection were recorded in bare-ground control plots beginning in mid-August (Fig. 2B). In 2014, the probability of trap plants infected with WSMV was high throughout autumn (Fig. 2). Relative to controls, mean probabilities of WSMV infection of trap plants were higher in spring downy brome plots in late September through October, between 2,329 and

Table 2. Akaike's information criterion (AIC) values for models of the proportion of wheat curl mite (WCM) (Aceria tosichella Keifer) and proportion of infection of Wheat streak mosaic virus (WSMV) in trap plants sampled during late summer and early autumn 2013, 2014, and 2015 in Bozeman, MT

\begin{tabular}{|c|c|c|c|}
\hline Model formula & $\mathbf{d f}^{\mathbf{b}}$ & $\begin{array}{c}\text { WCM } \\
\text { infestation }\end{array}$ & $\begin{array}{l}\text { WSMV } \\
\text { infection }^{\mathrm{c}}\end{array}$ \\
\hline $\begin{array}{l}\text { Mean temperature on day of } \\
\text { sampling }\end{array}$ & 3 & 1,405 & 1,541 \\
\hline Mean temperature 3 prior days & 3 & 1,430 & 1,543 \\
\hline Mean temperature 7 prior days & 3 & 1,411 & 1,530 \\
\hline GDD & 3 & 1,562 & 1,508 \\
\hline $\begin{array}{l}\text { Mean temperature on day of } \\
\text { sampling + GDD }\end{array}$ & 4 & 1,385 & $\mathrm{NA}$ \\
\hline $\begin{array}{l}\text { Mean temperature on day of } \\
\text { sampling } \times \text { GDD }\end{array}$ & 5 & 1,347 & NA \\
\hline $\begin{array}{l}\text { GDD + Mean temperature on } \\
\text { day of sampling }\end{array}$ & 4 & NA & 1,508 \\
\hline $\begin{array}{l}\text { GDD } \times \text { Mean temperature on } \\
\text { day of sampling }\end{array}$ & 5 & NA & 1,343 \\
\hline $\begin{array}{l}\text { Mean temperature on day of } \\
\text { sampling } \times \text { GDD }+ \text { alternative } \\
\text { host }\end{array}$ & 11 & 1,161 & NA \\
\hline $\begin{array}{l}\text { Mean temperature on day of } \\
\text { sampling } \times \text { GDD } \times \text { alternative } \\
\text { host }\end{array}$ & 29 & 1,070 & NA \\
\hline $\begin{array}{l}\text { GDD } \times \text { Mean temperature on } \\
\text { day of sampling }+ \text { alternative } \\
\text { host }\end{array}$ & 10 & NA & 1,244 \\
\hline $\begin{array}{l}\text { GDD } \times \text { Mean temperature on } \\
\text { day of sampling } \times \text { alternative } \\
\text { host }\end{array}$ & 28 & NA & 1,200 \\
\hline $\begin{array}{l}\text { Poly }(\text { day of the year, } 2) \times \text { year } \times \\
\text { alternative host }\end{array}$ & 17 & 1,233 & 1,175 \\
\hline
\end{tabular}

${ }^{a}$ Models were fit in response to the mean temperature on the day of sampling, the mean daily temperature 3 days prior to collection, the mean daily temperature 7 days prior to collection of plants in the field, cumulative growing degree-days (GDD), and surrounding alternative host.

${ }^{\mathrm{b}}$ Number of parameters in the model. $\mathrm{NA}=$ not applicable.

${ }^{c}$ The lowest AIC value indicates the most support for a model. NA = not applicable.

${ }^{\mathrm{d}}$ Model fit with parameters in time and the interactions of alternative hosts; poly(day of year, 2) indicates a second-order polynomial of day of the year.
2,373 GDD $(P<0.001)$, and in preharvest volunteer wheat plots around 1 September, at 1,867 to 1,956 GDD $(P<0.001)$. Probability of WSMV infection of trap plants surrounded by preharvest volunteer wheat plots was higher than the control from mid-August until mid-September, between 1,670 and 1,960 GDD. Postharvest volunteer wheat and green foxtail had lower WSMV infection rates on trap plants than the control at most other GDD $(P<0.01)$. In 2015, spring downy brome and preharvest volunteer wheat had a higher proportion of trap plants infected with WSMV relative to the control treatment throughout the sampling period (Fig. 2).

The bioclimatic model of WCM infestation and WSMV infection predicted that plots surrounded by spring downy brome and preharvest wheat have rates of infestation and infection of $99 \%$ of all plants on 25 October when the temperature is $20^{\circ} \mathrm{C}$, and $<1 \%$ on the same date when the temperature is $0^{\circ} \mathrm{C}$ (Supplementary File S1). The predicted WCM infestation and WSMV infestation values from the bioclimatic model were similar to observed WCM infestation and WSMV infection late in the season in a warm year (2015) and in a contrasting cold year (2013), respectively. These results partially validate the bioclimatic model (Figs. 1 and 2).

\section{Discussion}

Prevalence of a plant viral disease is affected by variables that include host, environment, and their interaction (Madden et al. 2007). The results from this study indicate that, in the Northern Great Plains, incidence of WCM and infection of wheat by WSMV are affected by temperatures during the autumn, surrounding grassy alternative hosts of WCM and WSMV, and maturity of alternative hosts predicted by GDD. To minimize disease outbreaks, farmers are encouraged to plant wheat later to avoid favorable periods for plant viral disease transmission and to avoid vectors (Hesler et al. 2005). However, disease management is complicated by the necessity of early winter wheat planting in northern regions to ensure good fall emergence and growth for high yield potential. Thus, there is often a narrow timeframe to plant when conditions for wheat growth are favorable and abundance of disease vectors are low (Jiang et al. 2005).

In this study, warm autumn temperatures favored WCM population growth which, in turn, may have facilitated movement to susceptible host plants (Slykhuis et al. 1957) and subsequent virus replication in

Table 3. Analysis of deviance tables for models of the proportion of trap plants infested with wheat curl mites (WCM) (Aceria tosichella Keifer) and the proportion of plants infected with Wheat streak mosaic virus (WSMV) in response to mean temperature on the day of sampling (mean temperature), cumulative growing degree-days (GDD), alternative host, and their interaction $^{\mathrm{a}}$

\begin{tabular}{lrc}
\hline Model & Deviance explained & $\boldsymbol{P}$ \\
\hline WCM infestation & & \\
Total deviance & 940 & \\
Mean temperature & 130 & $<0.001$ \\
GDD & 4 & 0.042 \\
Alternative host & 103 & $<0.001$ \\
Mean temperature $\times$ GDD & 42 & $<0.001$ \\
Mean temperature $\times$ alternative host & 12 & 0.056 \\
GDD $\times$ alternative host & 35 & $<0.001$ \\
Mean temperature $\times$ GDD $\times$ alternative & 22 & 0.001 \\
host & & \\
WSMV infection & 1,115 & \\
Total deviance & 60 & 0.001 \\
GDD & 3 & 0.092 \\
Mean temperature & 82 & $<0.001$ \\
Alternative host & 146 & $<0.001$ \\
GDD $\times$ mean temperature & 20 & 0.003 \\
GDD $\times$ alternative host & 14 & 0.04 \\
Mean temperature $\times$ alternative host & 17 & 0.011 \\
Mean temperature $\times$ GDD $\times$ alternative & & \\
host &
\end{tabular}

${ }^{\text {a }}$ Total deviance is all deviance of the response variable and $P$ is the probability derived from the likelihood ratio test. 
the plant (Wosula et al. 2017). When humidity and temperatures are moderate, WCM survive for the longest periods off host, and warm temperatures also support greater population growth of WCM on the host (Kuczyński et al. 2016; Wosula et al. 2015). Kuczyński et al. (2016) observed that WCM population growth rates above one, which indicate positive population growth, occur when temperatures range between 10 and $35^{\circ} \mathrm{C}$. Typical autumn temperatures in the primary winter wheat production region of Montana and many parts of the Northern Great Plains average $13^{\circ} \mathrm{C}$ in September and $7^{\circ} \mathrm{C}$ in October (PRISM Climate Group 2004), indicating the role that mean daily temperatures play in regulating the population growth of WCM during the period in which WSMV is transmitted. The results indicate that the highest prevalence of WSMV occurred later in the season, when mean daily temperature was greater than $10^{\circ} \mathrm{C}$, because population growth of WCM and virus replication in the plant occurred over a long period (Wosula et al. 2017). As climate continues to warm in the Northern Great Plains (Shafer et al. 2014), especially during autumn, longer and more favorable WCM conditions can be expected to increase risk of WSMV transmission.

The risk of WCM infestation and WSMV infection of trap plants was generally influenced by surrounding alternative hosts as compared with control, bare-ground plots, and this relationship was modified by temperature. In the first 2 years of the experiment, maize, green foxtail, and postharvest volunteer wheat had similar WCM infestation compared with controls, suggesting that these host species did not alter the risk of WSMV incidence, at least under these conditions. However, downy brome and preharvest volunteer wheat increased WCM infestation and disease incidence of trap plants relative to the control. This was especially true in the warmest year of the study, 2015, which had the greatest pressure from WCM and WSMV. This demonstrates that certain alternative host species increase risk of WSMV infection of the emerging winter wheat crop; however, impacts of these species are modified by temperature as they affect WCM movement.

High rates of WCM infestation and WSMV infection on trap plants when surrounded by spring downy brome and preharvest volunteer wheat compared with bare ground suggest that WCM can survive and reproduce successfully on alternative hosts and serve as WSMV inoculum sources (Bowden et al. 1991; Seifers et al. 2002). Lower and highly variable rates of WCM infection and WSMV infection of trap plants surrounded by green foxtail were noted, suggesting that this species, despite hosting WSMV and the WCM, does not increase risk of WSMV infection. This may indicate that environmental factors, possibly linked with phenology, do not result in a favorable period for pathogen transmission, or that susceptibility to WCM and WSMV susceptibility differs by WCM biotypes (Brey et al. 1998; Carew et al. 2009; Ito et al. 2012; Siriwetwiwat 2006; Somsen and Sill 1970).

Agronomic practices may help to break the disease cycle by allowing crop plants to escape the peak period of exposure to viruliferous mites (Holtzer et al. 1996), also known as eliminating the green bridge. When possible, this also can be accomplished by increasing crop diversity and rotating to dicots (e.g., lentils) and by simultaneously reducing the amount of weedy alternative grass species in the fields. Even if WSMV incidence is reduced in a field through agronomic practices such as altered timing of wheat harvest and planting, it is not likely to reduce WSMV incidence on the landscape without a collective effort. Furthermore, movement of the WCM is influenced by year-to-year variability in weather conditions and agronomic practices (Thomas et al. 2004); therefore, research will be needed to address the efficacy of crop diversity in reducing WSMV prevalence.

The results indicate that daily mean temperature and GDD of spring wheat represent appropriate parameters to predict risk of WCM infestation and WSMV infection in wheat systems across the Northern Great Plains. It will be useful to add other variables, including other hail events during grain maturity (Nguy-Robertson et al. 2016), landscape scale factors such as density of wheat and barley crops, and crop diversification. Based on knowledge in hand, the greatest incidence of WSMV is likely to occur in a year with a warm autumn and abundant alternative hosts such as volunteer wheat and spring-emerged downy brome.
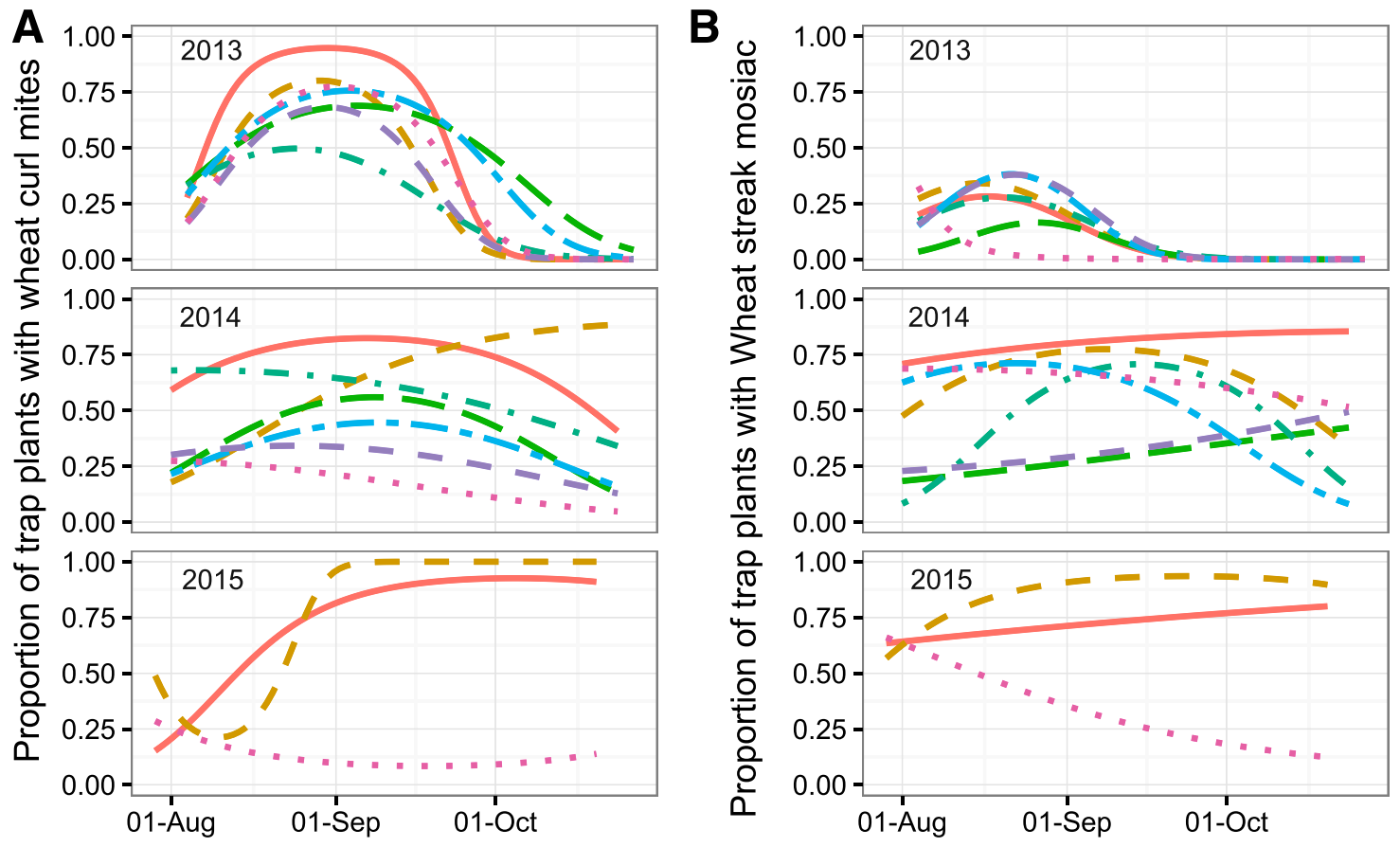

Date

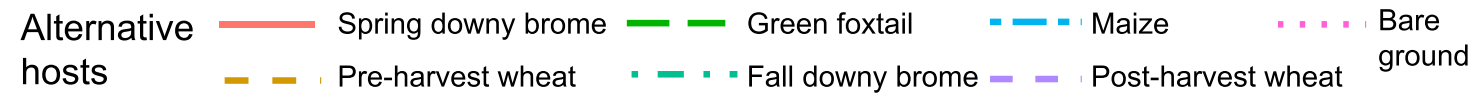

Fig 2. A, Regression models of the proportion of wheat trap plants infested with wheat curl mites (Aceria tosichella Keifer) in response to alternative hosts in 2013 (top), 2014 (middle), and 2015 (bottom) and B, regression models of the proportion of trap plants infected with Wheat streak mosaic virus in response to alternative hosts (displayed as date). 


\section{Acknowledgments}

We thank M. Brelsford, M. Departee, N. Arthun, B. Schaff, D. Gettel, and

E. Davis for assistance with laboratory and field operations.

\section{Literature Cited}

Bates, D., Maechler, M., Bolker, B., and Walker, S. 2015. Fitting linear mixed effects models using lme4. J. Stat. Soft. 67:1-48.

Bockus, W. W., Appel, J. A., Bowden, R. L., Fritz, A. K., Gill, B. S., Martin, T. J., Seifers, D. L., Brown-Guedira, G. L., and Eversmeyer, M. G. 2001. Success stories: Breeding for wheat disease resistance in Kansas. Plant Dis. 85:453-461.

Bowden, R. L., Brooks, H. L., Peterson, D. E., and Shroyer, J. P. 1991. Be a good neighbor: Control your volunteer wheat. Kans. State Univ. Ext. MF-1004.

Brey, C. W., Johnson, G. D., and Blodgett, S. L. 1998. Survey of Montana grasses for wheat curl mite the vector of Wheat streak mosaic virus. J. Agric. Entomol. 15:173-181.

Burnham, K. P., and Anderson, D. R. 2002. Model Selection and Multimodel Inference: A Practical Information-Theoretic Approach. Springer, New York.

Burrows, M., Thomas, C., McRoberts, N., Bostock, R. M., Coop, L., and Stack, J. 2016. Coordination of diagnostic efforts in the Great Plains: Wheat virus survey and modeling of disease onset. Plant Dis. 100:1037-1045.

Carew, M., Schiffer, M., Umina, P., Weeks, A., and Hoffmann, A. 2009. Molecular markers indicate that the wheat curl mite, Aceria tosichella Keifer, may represent a species complex in Australia. Bull. Entomol. Res. 99:479-486.

Connin, R. V. 1956. The host range of the wheat curl mite, vector of wheat streakmosaic. J. Econ. Entomol. 49:1-4.

Cunniffe, N. J., Koskella, B., Metcalf, C. J. E., Parnell, S., Gottwald, T. R., and Gilligan, C. A. 2015. Thirteen challenges in modelling plant diseases. Epidemics 10:6-10.

Dordas, C. 2008. Role of nutrients in controlling plant diseases in sustainable agriculture. A review. Agron. Sustain. Dev. 28:33-46.

French, R., and Stenger, D. C. 2003. Evolution of Wheat streak mosaic virus: Dynamics of population growth within plants may explain limited variation. Annu. Rev. Phytopathol. 41:199-214.

Graham, M. H. 2003. Confronting multicollinearity in ecological multiple regression. Ecology 84:2809-2815.

Hesler, L. S., Riedell, W. E., Langham, M. A. C., and Osborne, S. L. 2005. Insect infestations, incidence of viral plant diseases, and yield of winter wheat in relation to planting date in the Northern Great Plains. J. Econ. Entomol. 98:2020-2027.

Holtzer, T. O., Anderson, R. L., McMullen, P. M., and Peairs, B. F. 1996. Integrated pest management of insects, plant pathogens, and weeds in dryland cropping systems of the Great Plains. J. Prod. Agric. 9:200-208.

Hunger, R. M., Sherwood, J. L., Evans, C. K., and Montana, J. R. 1992. Effects of planting date and inoculation date on severity of wheat streak mosaic in hard red winter wheat cultivars. Plant Dis. 76:1056-1060.

Ito, D., Miller, Z., Menalled, F., Moffet, M., and Burrows, M. 2012. Relative susceptibility among alternative host species prevalent in the Great Plains to Wheat streak mosaic virus. Plant Dis. 96:1185-1192.

Jeger, M. J., Holt, J., Van Den Bosch, F., and Madden, L. V. 2004. Epidemiology of insect transmitted plant viruses: modelling disease dynamics and control interventions. Physiol. Entomol. 29:291-304.

Jiang, W., Garrett, K. A., Peterson, D. E., Harvey, T. L., Bowden, R. L., and Fang, L. 2005. The window of risk for emigration of Wheat streak mosaic virus varies with host eradication method. Plant Dis. 89:853-858.

Jones, R. A. C. 2014. Plant virus ecology and epidemiology: Historical perspectives, recent progress and future prospects. Ann. Appl. Biol. 164:320-347.

Juroszek, P., and von Tiedemann, A. 2011. Potential strategies and future requirements for plant disease management under a changing climate. Plant Pathol. 60:100-112.

Kuczyński, L., Rector, B. G., Kiedrowicz, A., Lewandowski, M., Szydło, W., and Skoracka, A. 2016. Thermal niches of two invasive genotypes of the wheat curl mite Aceria tosichella: Congruence between physiological and geographical distribution data. PLoS One 11:e0154600.

Lehnhoff, E., Miller, Z., Menalled, F., Ito, D., and Burrows, M. 2015. Wheat and barley susceptibility and tolerance to multiple isolates of Wheat streak mosaic virus. Plant Dis. 99:1383-1389.

Madden, L. V., Hughes, G., and van den Bosch, F. 2007. The Study of Plant Disease Epidemics. American Phytopathological Society, St. Paul, MN.

McMaster, G. S., and Wilhelm, W. W. 1997. Growing degree-days: One equation, two interpretations. Agric. For. Meteorol. 87:291-300.

Miller, P., Lanier, W., and Brandt, S. 2001. Using growing degree days to predict plant stages. Online publication. Mont. State Univ. Ext. Serv. Mont. Guide MT200103AG. http://store.msuextension.org/publications/agandnaturalresources/ mt200103ag.pdf

Miller, Z., Menalled, F., Ito, D., Moffet, M., and Burrows, M. 2014. Impacts of crop variety and time of inoculation on the susceptibility and tolerance of winter wheat to Wheat streak mosaic virus. Plant Dis. 98:1060-1065.

Miller, Z. J., Lehnhoff, E. A., Menalled, F. D., and Burrows, M. 2015. Effects of soil nitrogen and atmospheric carbon dioxide on Wheat streak mosaic virus and its vector (Aceria tosichella Kiefer). Plant Dis. 99:1803-1807.
Nakagawa, S, and Schielzeth, H. 2013. A general and simple method for obtaining $\mathrm{R}^{2}$ from generalized linear mixed-effects models. Methods Ecol. Evol. 4:133-142.

Navia, D., de Mendonça, R. S., Skoracka, A., Szydło, W., Knihinicki, D., Hein G. L., and Lau, D. 2013. Wheat curl mite, Aceria tosichella, and transmitted viruses: An expanding pest complex affecting cereal crops. Exp. Appl. Acarol. 59:95-143

Nguy-Robertson, A. L., Zygielbaum, A. I., McMechan, A. J., Hein, G. L., Wegulo, S. N., Stilwell, A. R., and Smith, T. M. 2016. Developing the framework for a risk map for mite vectored viruses in wheat resulting from pre-harvest hail damage. Crop Prot. 89:21-31.

PRISM Climate Group. 2004. PRISM Climate Data. Online publication. Oregon State University. http://prism.oregonstate.edu

Rahman, F., Ross, J. G., and Gardner, W. S. 1974. Tolerance to Wheat streak mosaic virus in spring and winter wheat cultivars. Crop Sci. 14:178-180.

R Development Core Team. 2014. R: A Language and Environment for Statistical Computing. R Foundation for Statistical Computing, Vienna

Scholthof, K.-B. G. 2007. The disease triangle: Pathogens, the environment and society. Nat. Rev. Microbiol. 5:152-156.

Seifers, D. L., Harvey, T. L., Louie, R., Gordon, D. T., and Martin, T. J. 2002. Differential transmission of isolates of the High Plains virus by different sources of wheat curl mites. Plant Dis. 86:138-142.

Shafer, M., Ojima, D., Antle, J. M., Kluck, D., McPherson, R. A., Petersen, S., Scanlon, B., and Sherman, K. 2014. Great Plains. Pages 441-461 in: Climate Change Impacts in the United States: The Third National Climate Assessment. J. M. Melillo, T. (T. C.) Richmond, and G. W. Yohe, eds. U.S. Global Change Research Program. U.S. Government Printing Office, Washington, DC.

Sharp, G. L., Martin, J. M., Lanning, S. P., Blake, N. K., Brey, C. W., Sivamani, E., $\mathrm{Qu}$, R., and Talbert, L. E. 2002. Field evaluation of transgenic and classical sources of resistance. Crop Sci. 42:105-110.

Siriwetwiwat, B. 2006. Interactions between the wheat curl mite, Aceria tosichella Keifer (Eriophyidae), and Wheat streak mosaic virus and distribution of wheat curl mite biotypes in the field. Thesis, UMI Number 3237062, University of Nebraska, Lincoln.

Skoracka, A. 2004. Eriophyoid Mites from Grasses in Poland. Polish Taxonomical Society, Wroclaw, Poland.

Skoracka, A., Lewandowski, M., Rector, B. G., Szydło, W., and Kuczyński, L. 2017. Spatial and host-related variation in prevalence and population density of wheat curl mite (Aceria tosichella) cryptic genotypes in agricultural landscapes. PLoS One 12:e0169874.

Slykhuis, J. 1955. Aceria tulipae Keifer (Acarina: Eriophyidae) in relation to the spread of wheat streak mosaic. Phytopathology 45:116-128.

Slykhuis, J. T., Andrews, J. E., and Pittman, U. J. 1957. Relation of date of seeding winter wheat in southern Alberta to losses from wheat streak mosaic, root rot, and rust. Can. J. Plant Sci. 37:113-127.

Somsen, H. W., and Sill, W. H., Jr. 1970. The wheat curl mite, Aceria tulipae Keifer, in relation to epidemiology and control of wheat streak mosaic. Kans. State Univ. Agric Exp. Stn. Res. Publ. 162.

Thomas, J., and Hein, G. 2003. Influence of volunteer wheat plant condition on movement of the wheat curl mite, Aceria tosichella, in winter wheat. Exp. Appl. Acarol. 31:253-268.

Thomas, J. A., Hein, G. L., and Lyon, D. J. 2004. Spread of wheat curl mite and Wheat streak mosaic virus is influenced by volunteer wheat control methods. Plant Health Prog. 23:1-6.

USBR. 2015. AgriMet: Weather \& Crop Water Use Charts. Online publication. The Great Plains Cooperative Agricultural Weather Network. United State Bureau of Reclamation (USBR), Department of the Interior, Great Plains, AgriMet Station BOZM, Bozeman, MT. https://www.usbr.gov/gp/agrimet/ station_bozm_bozeman.html

USDA-NASS. 2015. Montana crop progress and conditions report, 2014. Online publication. United States Department of Agriculture-National Agricultural Statistics Service (USDA-NASS), Washington, DC. https://www.nass.usda. gov/

USDA-NRCS. 2015. Web Soil Survey. Online publication. Soil Survey Staff, United States Department of Agriculture-Natural Resources Conservation Service (USDA-NRCS). https://websoilsurvey.nrcs.usda.gov/

Velandia, M., Rejesus, R., Jones, D., Price, J., Workneh, F., and Rush, C. 2010. Economic impact of Wheat streak mosaic virus in the Texas High Plains. Crop Prot. 29:699-703.

Watson, M. A., Heathcote, G. D., Lauckner, F. B., and Sowray, P. A. 1975. The use of weather data and counts of aphids in the field to predict the incidence of yellowing viruses of sugar-beet crops in England in relation to the use of insecticides. Ann. Appl. Biol. 81:181-198.

Wosula, E. N., McMechan, A. J., and Hein, G. L. 2015. The effect of temperature, relative humidity, and virus infection status on off-host survival of the wheat curl mite (Acari: Eriophyidae). J. Econ. Entomol. 108:1545-1552.

Wosula, E. N., Tatineni, S., Wegulo, S. N., and Hein, G. L. 2017. Effect of temperature on wheat streak mosaic disease development in winter wheat Plant Dis. 101:324-330. 